\title{
Biomarker of buccal mucosa cells damaged after exposure to panoramic radiography: a literature review
}

\author{
Dwi Putri Wulansari ${ }^{1,2^{*}}$, Azhari $^{3}$
}

\begin{abstract}
Objectives: This review aimed to understand the effect of exposure to panoramic radiographs on exfoliated buccal mucosal cells at the cellular level.

Review: The dose of radiation exposure in dentistry, both intraoral and extraoral, has been regulated by The National Radiological Protection Board (NRPB). However, even though it is given in small doses, $x$ ray radiation due to intraoral and extraoral radiographs still has a radiobiological effect on the exposed tissue. The radiobiological effects of X-ray exposure can cause changes in biological molecules, either directly or indirectly, within hours or days. There are two classification of this radiobiological effect, called deterministic and stochastic effect. The deterministic effect occurs when the dose given

adverse impact to the exposed tissue One method used as a predictor or biomarker of genetic damage due to exposure to physical or chemical mutagenic agents in humans is micronucleus (MN). The biomarker for the cell damaged is the change of nucleus shape and outline, called pycnosis, karyolysis, karyorrhexis.

Conclusion: The exposed to $x$-ray from panoramic could induce cell and genetic damaged. Prescription for panoramic radiographic examination in patients should be as effectively as possible according to the principles of ALADA (as low as diagnostically acceptable) to avoid adverse effects on the exposed tissue.
\end{abstract} exceeds the recommended dose by the NRPB, whereas the stochastic effect does not have any threshold that needs to be exceeded to give some

Keywords: Exfoliated buccal mucosal cells, micronucleus, cytotoxic, genotoxic

Cite this article: Wulansari DP, Azhari A. Biomarker of buccal mucosa cells damaged after exposure to panoramic radiography: a literature review. Jurnal Radiologi Dentomaksilofasial Indonesia 2021;5(1)27-30. https://doi.org/10.32793/ jrdi.v5i1.675

\section{INTRODUCTION}

${ }^{1}$ Department of Oral and Maxillofacial Radiology, Faculty of Dentistry, Universitas Hasanuddin, Makassar, Indonesia 90245

${ }^{2}$ Dentomaxillofacial Radiology Residency Program, Faculty of Dentistry, Universitas Padjadjaran, Bandung, Indonesia 40132

${ }^{3}$ Department of Dentomaxillofacia Radiology, Faculty of Dentistry, Universitas Padjadjaran, Bandung, Indonesia 40132

*Correspondence to:

Dwi Putri Wulansari

$\bowtie$ dwiputriwulansari51@gmail.com

Received on: February 2021

Revised on: March 2021

Accepted on: April 2021
The dose of radiation exposure in dentistry, both intraoral and extraoral, has been regulated by The National Radiological Protection Board (NRPB). However, even though it is given in small doses, $x$ ray radiation due to intraoral and extraoral radiographs still has a radiobiological effect on the exposed tissue. ${ }^{1}$ These radiobiological effects can cause changes in molecular biology, either directly or indirectly, within hours or days There are two classification of this radiobiological effect, called deterministic and stochastic effect. The deterministic effect occurs when the dose given exceeds the recommended dose by the NRPB, whereas the stochastic effect does not have any threshold that needs to be exceeded to give some adverse impact to the exposed tissue. ${ }^{2}$

One method that can be used as a predictor or biomarker of genetic damage due to exposure to physical or chemical mutagenic agents in humans is the micronucleus test $(\mathrm{MN})^{3,4}$. This micronucleus comes from chromosome fragments or al chromosomes that are left behind during the anaphase process. An increase in micronucleus frequency indicates chromosomal damage. The micronucleus can easily be assessed on erythrocytes, lymphocytes, and exfoliated epithelial cells in the oral, urothelial, or nasal areas. Micronucleus examination of exfoliated buccal cells is a minimally invasive method of monitoring human genetic defects and has been used since the 1980s. ${ }^{5}$

Beside the formation of micronucleus, the x-ray radiation that given in panoramic radiograph can lead to cell damage (cytotoxic). This cell damage can be seen from several cell changes that occur after panoramic exposure, such as damage to the cell nucleus, which is marked by the dissolution of chromosomes (pycnosis), the dissolution of chromatin in the cell nucleus (karyolysis), the rupture of the cell nucleus and the breakdown of chromatin (karyorrhexis). ${ }^{6}$ 


\section{REVIEW}

\section{FORMATION OF MICRONUCLEUS AND DAMAGED DUE TO X-RAY RADIATION}

The micronucleus originates primarily from acentric chromosome fragments, acentric chromatid fragments, or entire chromosomes that fail to be included in the nuclei at telophase completion during mitosis because the chromosome fragments or chromosomes do not adhere well to the spindle during the separation process in anaphase (Figure 1). These chromosomes or chromosome fragments that are not attached are eventually closed by a nuclear membrane which is morphologically similar to the nucleus after conventional nuclear staining but with a smaller size. $^{7}$

Several mechanisms form the acentric chromosome fragments. Studies of radiation biology over several decades have shown that repair errors in double-chain DNA breakdown can lead to an asymmetric and symmetrical exchange of chromosomes and chromatids and exchange of chromatids and chromosome fragments. A fraction of the acentric chromosome fragments results from the unrepaired breakdown of double-chain DNA But this is only possible when the burden of DNA damage exceeds the cell repair capacity within a certain time. ${ }^{7}$ From research conducted by KyungMi Choi et al. in 2006, it was concluded that x-ray radiation can cause DNA damage through the process of damage to DNA breakdown or by producing reactive oxygen species (ROS). From these studies it is known that ROS is a mediator of micronucleus formation due to irradiation. ${ }^{8}$

The molecular mechanism of $\mathrm{x}$-ray radiationinduced cellular damage depends on several factors, including dose, length of exposure, cell type, and the cells' status transformed. In some cases, the susceptibility of certain tissues and organ systems has different radio-sensitivities. The susceptibility of tissue to radiation damage is stated by Bergonie and Trebondeau's Law which states that ionizing radiation is generally more destructive in rapidly dividing cells and in undifferentiated cells. ${ }^{9}$

Cell death, both necrosis and apoptosis, occur due to the induction of $\mathrm{x}$-ray radiation characterized by irreversible changes in the nucleus and cytoplasm. These irreversible changes in the nucleus include pycnosis (the process of damage to the cell nucleus characterized by the dissolution of chromosomes and the condensation process in the cell nucleus), karyolysis (the process of dissolving chromatin in the cell nucleus that occurs naturally or due to damage to body tissues) and karyorrhexis. (a process of cell damage characterized by the rupture of the cell nucleus and the breakdown of chromatin). ${ }^{10}$

\section{DISCUSSION}

The buccal mucosa is the main barrier in the oral cavity, both inhalation, and ingestion, and can metabolize carcinogenic compounds into reactive

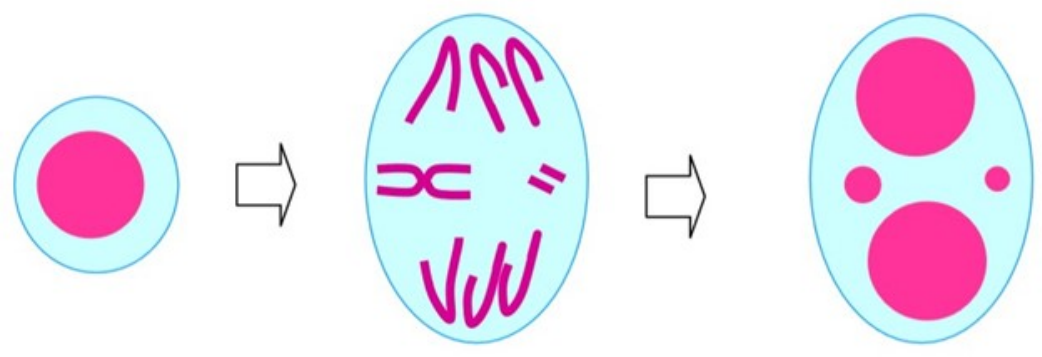

Figure 1. Micronucleus originates from asentric chromosome fragments or entire chromosomes that are left behind ${ }^{5}$

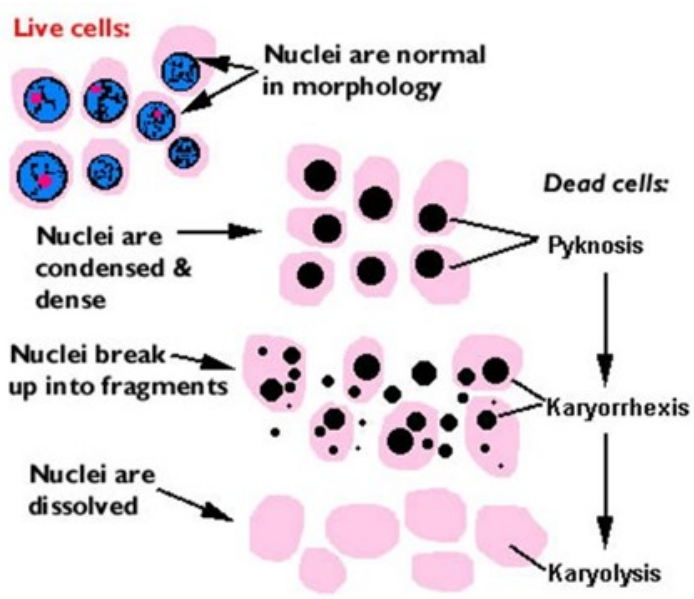


Table 1. Studies on genetic and cell damaged induced by dental X-rays

\begin{tabular}{|c|c|c|c|}
\hline Author's (Year) & Subject & Type of Dental X-Ray & Findings \\
\hline Cerqueira et al. (2004) & $\begin{array}{l}\text { Exfoliated cells from } \\
\text { oral mucosa }\end{array}$ & Panoramic & $\begin{array}{l}\text { Non-significant genetic damaged } \\
\text { Significant cell damaged }\end{array}$ \\
\hline Popova L et al. (2007) & Buccal mucosa cells & Panoramic & Non-significant genetic damaged \\
\hline Cerqueira et al. (2008) & $\begin{array}{l}\text { Keratinized mucosa } \\
\text { cells }\end{array}$ & Panoramic & $\begin{array}{l}\text { Significant genetic and cell dam- } \\
\text { aged }\end{array}$ \\
\hline Arora P et al. (2014) & $\begin{array}{l}\text { Buccal mucosa and } \\
\text { gingival cells }\end{array}$ & Panoramic & Significant genetic damaged \\
\hline Vidya KB et al. (2014) & Buccal mucosa cells & Panoramic & Significant genetic damaged \\
\hline Haghgoo R et al. (2014) & Buccal mucosa celsl & Panoramic & Non-significant genetic damaged \\
\hline Agarwal P et al.(2015) & Buccal mucosa cells & Panoramic & $\begin{array}{l}\text { Non-significant genetic damaged } \\
\text { Significant cell damaged }\end{array}$ \\
\hline Sandhu M et al. (2015) & Buccal mucosa cells & Panoramic & Significant genetic damaged \\
\hline Preethi N et al. (2016) & Buccal mucosa cells & Panoramic & Significant genetic damaged \\
\hline Antonio EL et al. (2017) & Oral mucosa cells & Panoramic & $\begin{array}{l}\text { Non-significant genetic damaged } \\
\text { Significant cell damaged }\end{array}$ \\
\hline Kesidi S et al. (2017) & Buccal mucosa cells & Panoramic & Non-significant genetic damaged \\
\hline Li G et al. (2018) & Buccal mucosa cells & Panoramic & $\begin{array}{l}\text { Significant genetic and cell dam- } \\
\text { aged }\end{array}$ \\
\hline
\end{tabular}

products. As much as $90 \%$ of human cancers originate from epithelial cells, and the buccal mucosal epithelial cells can reflect the cell area where the initial genotoxic processes induced by carcinogenic agents enter through the oral cavity. The exfoliated buccal mucosa epithelial cells were chosen to be the research object of some researchers because the retrieval process is relatively easy and fast, non-invasive, does not require culture and stimulation processes. ${ }^{11}$

The sample collection of exfoliated buccal mucosa cells was carried out within $10 \pm 2$ days after exposure to $\mathrm{x}$-rays because it followed the turnover time from the basal layer to the epithelial layer which had the fastest migration rate between week 1 to week 3 (7-21 days) after exposure. Some literature suggests the maximum take is in the range of 8-12 days. ${ }^{3,12}$

The formation of micronucleus in exfoliated buccal mucosa cells after exposed to panoramic radiograph was found in several research that conducted by Cerqueira et al. (2008), Arora P et al. (2014), Vidya KB et al. (2014), Preethi $N$ et al. (2016), Sandhu M et al. (2015), Li G et al. (2018). Their publication showed that there was a significant increase in the amount of micronucleus in exposed group. ${ }^{12-17}$ The increase in the number of micronucleus indicated a genomic instability and was thought to be associated with an increase in carcinogenic effects. The differences in the micronucleus of the samples in the same group could be caused by chromosome alteration. ${ }^{13}$ The micronucleus formation occured because of damage at the chromosome level when cells divide from the basal layer to the epithelium of the buccal mucosal cells and can only be observed from exfoliated cells after the differentiation process occurs. ${ }^{12}$

From the histopatological examination, some of research that conducted by Cerqueira et al. (2004,2008), Agarwal P et al.(2015), Antonio EL et al. (2017), Li G et al. (2018) it was found that the $x-$ ray radiation giving in panoramic radiograph could induced the morphological change in nucleus form. Their publication showed that there were an increase in the number of pycnosis, karyolysis, and karyorrhexis of exfoliated buccal mucosa cells exposed to panoramic radiography. ${ }^{3,13,17,18}$ This increase indicated that in this study panoramic radiographs induce an apoptotic response characterized by an increase in the number of pycnosis and karyorrhexis, and also induce a necrotic response characterized by an increase in the number of karyolysis.

The changes that occur in exfoliated buccal mucosal cells after $x$-ray exposure was a sign that $x$ ray exposure from panoramic radiographs could give an effect at the cellular level. Although the effect does not seen immediately, this effect should be considered before prescribing a diagnostic radiological examination.

\section{CONCLUSION}

The exposed to $x$-ray from panoramic could induce cell and genetic damaged. The prescription of radiology examinations that can provide $x$-ray exposure to patients should be done as effectively as possible according to standard radiographic examination procedures and ALADA (as low as diagnostically acceptable) principles to avoid stochastic effects. 


\section{ACKNOWLEDGMENTS}

None.

\section{FOOTNOTES}

All authors have no potential conflict of interest to declare for this article.

\section{REFERENCES}

1. Mupparapu M, Shi KJ, Ko E. Differential diagnosis of periapica radiopacities and radiolucencies. Dent Clin North Am. 2020;64 (1):163-89

2. Demir A, Pekiner FN. Idiopathic Osteosclerosis of the jaws in turkish subpopulation: cone-beam computed tomography findings. Clin Exp Heal Sci. 2019;

3. Gamba TO, Maciel NAP, Rados PV, da Silveira HLD, Arús NA, Flores IL. The imaging role for diagnosis of idiopathic osteosclerosis: a retrospective approach based on records of 33,550 cases. Clin Oral Investig. 2021;25(4):1755-65.

4. Ahmad NS, Yong J, Mei S, Ibrahim N, Fauzi AA, Megat $R$, et al. Asymptomatic radiopacity of mandible causing delayed orthodontic tooth movement : A Case Report. J Res Med Den Sci. 2020;8(2):72-5.

5. Tsvetanov T. Mandibular idiopathic osteosclerosis or condensing osteitis. A Case Report. Int J Med Dent. 2020;24 (4):604-6.

6. Farhadi F, Ruhani MR, Zarandi A. Frequency and pattern of idiopathic osteosclerosis and condensing osteitis lesions in panoramic radiography of Iranian patients. Dent Res (Isfahan). 2016;13(4):322-6.

7. Adisen M, Yilmaz S, Misirlioglu M, Nalcaci R. The evaluation of idiopathic osteosclerosis on panoramic radiographs with a investigation of lesion's relationship with mandibular canal by using cross-sectional cone-beam computed tomography images. J Oral Maxillofac Radiol. 2013;1(2):48.

8. Sisman $\mathrm{Y}$, Ertas $\mathrm{ET}$, Ertas $\mathrm{H}$, Sekerci AE. The frequency and distribution of idiopathic osteosclerosis of the jaw. Eur J Dent. 2011 Aug:5(4):409-14.

9. Azizi Z, Mosafery H, Safi Y, Dabirzadeh S, Vasegh Z. Prevalence of idiopathic osteosclerosis on cone beam computed tomography images. J Dent Sch Shahid Beheshti Univ Med Sci. 2017;35(2):67-70.

10. Zayet MK, Hassan AA. Assessment of idiopathic osteosclerosis in the jaws of the egyptian population using cone beam computed tomography. 2019;65:1397-401.

11. Li Z, Lai R, Feng Z. Case history report: cone beam computed tomography for implant insertion guidance in the presence of a dense bone island. Int J Prosthodont. 2016;29(2):186-7.

12. White SC, Pharoah MJ, Oral radiology principle and interpretation. 7th edition. St. Louis Missouri; 2014.

13. Sinnott PM, Hodges S. An incidental dense bone island: A review of potential medical and orthodontic implications of dense bone islands and case report. J Orthod. 2020;47(3):251 $-6$

14. Ledesma-Montes $C$, Jiménez-Farfán MD, Hernández-Guerrero JC. Idiopathic osteosclerosis in the maxillomandibular area. Radiol Medica [Internet]. 2019;124(1):27-33.

15. Verzak Z, Celap B, Modrić VE, Sorić P, Karlović Z. The prevalence of idiopathic osteosclerosis and condensing osteitis in Zagreb population. Acta Clin Croat. 2012 Dec;51 (4):573-7.

16. Rahman FUA, Epsilawati L, Pramanik F, Febriani M. Temuan insidental lesi radiopak asimptomatik pada pemeriksaan radiografi panoramik: laporan 3 kasus dan ulasan pustaka Dense Bone Island (DBI). J Radiol Dentomaksilofasial Indones. 2019;3(2):35.

17. Silva BSF, Bueno MR, Yamamoto-Silva FP, Gomez RS, Peters $\mathrm{OA}$, Estrela C. Differential diagnosis and clinical management of periapical radiopaque/hyperdense jaw lesions. Braz Oral Res. 2017;31:e52.

18. Chen $\mathrm{CH}$, Wang $\mathrm{CK}$, Lin LM, Huang Y Der, Geist JR, Chen YK. Retrospective comparison of the frequency, distribution, and radiographic features of osteosclerosis of the jaws between Taiwanese and American cohorts using cone-beam computed tomography. Oral Radiol. 2014;30(1):53-63.

19. Tie C, Zhi-ying Z. Cone beam computed tomography: a useful tool in diagnosis of bone ssland and implant insertion guidance. Omi J Radiol. 2012;01(02)

20. Whaites E, Drage N, Essentials of dental radiography and radiology. 5th edition. Elsevier; 2013. p.193. 